A RCHIWA, BIBLIOTEKI

I MUZEA KOŚCIELNE 112 (2019)

https://doi.org.10.31743/abmk.2019.112.23

ŁUKASZ WŁODARSKI* - TORUŃ

\title{
KILKA UWAG O FORMULARZU LISTÓW SZYMONA MACIEJOWI- CA ZE STAWU NA PRZYKLADZIE KORESPONDENCJI OFICJALA KAMIEŃSKIEGO I POMORSKIEGO Z WIELKIMI MISTRZAMI KRZYŻACKIMI W PRUSACH ORAZ RADĄ MIASTA GDAŃSKA**
}

\begin{abstract}
Streszczenie
Artykuł stawia sobie za cel przedstawienie elementów formularza listów oficjała kamieńskiego i zarazem tamtejszego wikariusza in spiritualibus et temporalibus (chwilowo również oficjała pomorskiego) Szymona Maciejowica ze Stawu do adresatów w Prusach, a ściślej do wielkich mistrzów krzyżackich oraz rajców gdańskich. Niestety po dziś dzień, w oryginale zachowało się jedynie siedem listów tegoż dygnitarza kościelnego. Niemniej w świetle interesującej nas korespondencji rzeczą symptomatyczną jest, iż Szymon w stosunku do adresatów tytułował się ich kapelanem (cappellanus). Zwrot ten w swej naturze kurtuazyjny, de facto był synonimem osoby duchownej. Warto również podkreślić, iż Maciejowic niejednokrotnie, zapewne aby upodobać się odbiorcy i zyskać jego przychylność, w listach adresowanych do wielkich mistrzów krzyżackich używał w stosunku do nich tytulatury książęcej. Dodać wreszcie należy, iż w warunkach polskiej dyplomacji tytułowanie zwierzchnika Zakonu Krzyżackiego księciem staje się praktyką dość powszechną dopiero po roku 1466, a więc po podpisaniu tzw. II pokoju toruńskiego.
\end{abstract}

Słowa kluczowe: Prusy; Szymon Maciejowic ze Stawu; oficjalat kamieński; oficjalat pomorski; XV wiek; dyplomatyka

W tradycji polskiej historiografii poczesne miejsce zajmują badania nad dyplomatyką. Dotychczas dominowały jednak rozważania rozważania skupiające się wokół kancelarii monarszych (królewskich i książęcych) oraz biskupich, co oczywiście związane jest ze stanem zachowania bazy źródłowej. Egzemplifikacją tych

* Łukasz Włodarski - mgr historii; doktorant w Instytucie Historii i Archiwistyki Uniwersytetu Mikołaja Kopernika w Toruniu; e-mail: wlodarski24@gmail.com

https://orcid.org/0000-0001-8615-1835

** Praca naukowa finansowana ze środków budżetowych na naukę w latach 2014-2018 jako projekt badawczy w ramach programu pod nazwą „Diamentowy Grant”. 
pierwszych niech będą prace Ireny Sułkowskiej-Kurasiowej ${ }^{1}$, czy ostatnio Adama Szwedy $^{2}$ traktujące o kancelariach królewskich i ich produktach w XIV-XV stuleciu, a także publikacje Sobiesława Szybkowskiego ${ }^{3}$ dotyczące epistolografii książąt mazowieckich. $Z$ kolei dla badań nad dokumentami hierarchów kościelnych niech tytułem przykładu posłużą monografie Marii Koczerskiej ${ }^{4}$ oraz Zofii Wilk-Wośs. Tej problematyki dotykają również opracowania syntetyczne m.in. Dyplomatyka wieków średnich pióra trojga autorów Karola Maleczyńskiego, Marii Bielińskiej i Antoniego Gąsiorowskiego ${ }^{6}$, Kancelarie na Mazowszu autorstwa Ewy Suchodolskiej $^{7}$, czy Dyplomatyka staropolska pod redakcją Tomasza Jurka ${ }^{8}$. Jak dotąd właściwie nie podejmowano żadnych prac mających na celu przedstawienie epistolografii oficjałów bądź wikariuszy in spiritualibus et temporalibus, dlatego w pełni uzasadnione wydaje się być poruszenie tego wątku w literaturze przedmiotu9.

Celem niniejszego artykułu jest ukazanie elementów formularza listów oficjała kamieńskiego i tamtejszego wikariusza in spiritualibus et temporalibus (później również oficjała pomorskiego) Szymona Maciejowica ze Stawu do adresatów w Prusach, a ściślej do wielkich mistrzów krzyżackich oraz do rady miasta Gdańska. Przypadek ten jest o tyle frapujący, że Szymon jako oficjał, czyli osoba m.in. wydająca wyroki sądowe w imieniu ordynariusza, należał bezsprzecznie do

${ }^{1}$ I. Sułkowska-Kurasiowa, Polska kancelaria królewska w latach 1447-1506, Wrocław 1967; taż, Dokumenty królewskie i ich funkcja w państwie polskim za Andegawenów i pierwszych Jagiellonów (1370-1444), Warszawa 1977.

${ }^{2}$ A. Szweda, Listy Władysława Jagielty do wielkich mistrzów krzyżackich w latach 1386-1434, w: Tekst źródła - krytyka, interpretacja, red. B. Trelińska, Warszawa 2005, s. 253-272; tenże, Listy króla Polski Kazimierza Jagiellończyka do wielkich mistrzów zakonu krzyżackiego z lat 1447-1454, w: Bitwa pod Chojnicami 18 IX 1454 r. w tradycji historycznej i lokalnej, red. J. Knopek, B. Kuffel, Chojnice 2004, s. 14-32; tenże, Organizacja i technika dyplomacji polskiej w stosunkach z zakonem krzyżackim $w$ Prusach w latach 1386-1454, Torun 2009.

${ }^{3}$ S. Szybkowski, Listy ksiażą mazowieckich do gdańskiej rady miejskiej (do końca wojny trzynastoletniej), „Archeion”, 113 (2012) s. 217-248; tenże, Korespondencja książat mazowieckich z Rada Miasta Gdańska w latach 1466-1526, w: Dziedzictwo ksiażąt mazowieckich. Stan badań i postulaty badawcze, red. J. Grabowski, R. Mroczek, P. Mrozowski, Warszawa 2017, s. 283-304.

${ }^{4}$ M. Koczerska, Zbigniew Oleśnicki i Kościót krakowski w czasach jego pontyfikatu 1423-1455, Warszawa 2004.

${ }^{5}$ Z. Wilk-Woś, Późnośredniowieczna kancelaria arcybiskupów gnieźnieńskich (1436-1493), Łódź 2013.

${ }^{6}$ Dyplomatyka wieków średnich, oprac. K. Maleczyński, M. Bielińska, A. Gąsiorowski, Warszawa 1971. W tym miejscu wypada również wspomnieć o S. Kętrzyński, Zarys nauki o dokumencie polskim wieków średnich, t. 1, Warszawa 1934 oraz K. Maleczyński, Zarys dyplomatyki polskiej wieków średnich, cz. 1, Wrocław 1951.

${ }^{7}$ E. Suchodolska, Kancelarie na Mazowszu w latach 1248-1345.Ośrodki zarządzania i kultury, Warszawa 1977.

${ }^{8}$ Dyplomatyka staropolska, red. T. Jurek, Warszawa 2015.

9 Jedynie M. Koczerska (Kancelaria i dokumentacja kościelna, w: Dyplomatyka staropolska, s. 359-367) poświęca niewielki passus dotyczący funkcjonowania kancelarii konsystorskich, którymi zarządzał oficjał. Omówiono tam również wybrane dyplomy i listy samych oficjałów, jednak siłą rzeczy dotyczyły one wyłącznie spraw sądowych (wyroki sądowe, pozwy, pisma procesowe). 
najbliższego otoczenia arcybiskupiego ${ }^{10}$, zaś w pismach ekspediowanych przez niego do wielkich mistrzów oraz do rajców gdańskich za każdym razem występuje on jako ich „capellanus”, a jednokrotnie posługuje się w stosunku do zwierzchnika Zakonu Krzyżackiego określeniem „orator”.

Na łamach Polskiego Stownika Biograficznego ukazał się ostatnio życiorys Szymona ze Stawu pióra Antoniego Gąsiorowskiego i Izabeli Skierskiej ${ }^{11}$. Toteż na potrzeby niniejszego szkicu ograniczymy się jedynie do zreferowania najważniejszych ustaleń wspomnianych badaczy. Szymon był synem Macieja ze Stawu (ziemia sieradzka). W latach 1404-1407 był pisarzem biskupa poznańskiego Wojciecha Jastrzębca. Następnie w 1414 r. mianowany został przez arcybiskupa gnieźnieńskiego Mikołaja Trąbe wikariuszem in spiritualibus et temporalibus w Kamieniu oraz tamtejszym oficjałem. Jego jurysdykcją objęta została północna część archidiakonatu gnieźnieńskiego (w granicach Polski - ziemia nakielska, zaś po stronie władztwa zakonnego okręgi człuchowski i tucholski). Ponadto obok urzędu wikariusza i oficjała kamieńskiego, jako tamtejszy tenutariusz zarządzał kluczem dóbr arcybiskupich skupionych wokół Kamienia. Około 1418/1419 r. przebywał przy prymasie będąc jego prokuratorem w sprawach prowadzonych przed sądami, zaś w latach 1419-1420 był kanclerzem (podkanclerzym) Mikołaja Trąby. W 1423 r. arcybiskup Wojciech Jastrzębiec przywrócił go na oficjalat kamieński, by następnie w latach 1425-1430 pełnić również urząd tamtejszego wikariusza generalnego. W 1434 r., z ramienia biskupa włocławskiego Władysława Oporowskiego, był wikariuszem in spiritualibus oraz oficjałem pomorskim, by w roku następnym wrócić do Kamienia na sprawowane uprzednio godności. W dniu 1 stycznia $1436 \mathrm{r}$. Wojciech Jastrzębiec, w myśl postanowień pokoju brzeskiego, wyznaczył Szymona na swojego prokuratora i posła w celu pobrania od Krzyżaków zaległych czynszów z ostatnich dwóch lat oraz dziesięcin ze wsi arcybiskupich położonych na Pomorzu, zaś z nominacji prymasa Wincentego Kota został on oficjałem kaliskim (1439-1440). Posiadał również szereg innych beneficjów kościelnych (m.in. kanonikat kaliski; kustodię, kanonikat oraz wikariat łęczycki, ponadto był plebanem w Chełmcach i Stawie) ${ }^{12}$. Do powyższych informacji warto również dodać, że Szymon 22 sierpnia 1422 r. był testatorem powołania na świadka oraz zaprzysiężenia - podczas procesu toczącego się przed wysłanni-

${ }^{10}$ S. Librowski, Wizytacje diecezji włoctawskiej, cz. I, Wizytacje diecezji kujawskiej i pomorskiej, t. 1, Opracowanie archiwalno - źródtoznawcze, „Archiwa, Biblioteki i Muzea Kościelne”, 8 (1964) s. 55-60 (dwór); s. 66-69 (oficjał i wikariusz generalny); I. Skierska, Dwór i urząd biskupi w późnośredniowiecznej diecezji poznańskiej, „Roczniki Historyczne”, 60 (1994) s. 185-202.

${ }^{11}$ A. Gąsiorowski, I. Skierska, Szymon ze Stawu, w: Polski Stownik Biograficzny, t. 50/2, z. 205, Warszawa-Kraków 2015, s. 282-284. Lista oficjałów kamieńskich jak dotąd pozostaje niepełna por. A. Gąsiorowski, I. Skierska, Poczatki oficjalatu kamieńskiego archidiecezji gnieźnieńskiej (wieki $X I V-X V)$, „Kwartalnik Historyczny” 103 (1996) nr 2, s. 19-20 (Aneks) - tu jedynie dla XV stulecia.

${ }^{12}$ Gąsiorowski, Skierska, Szymon ze Stawu, s. 282-284. 
kiem papieskim Antonim Zeno z Mediolanu - scholastyka łęczyckiego Wojciecha z Bielaw ${ }^{13}$. Zmarł przed 10 lipca 1452 r. $^{14}$

$\mathrm{W}$ trakcie kwerendy udało się nam odnaleźć siedem oryginalnych listów ${ }^{15}$, których wystawcą był Szymon ze Stawu. Pierwszy z nich nosi jedynie datę dzienną ,ipso die sancte Dorothee virginis”, tzn. 6 lutego, ale kontekst historyczny wskazuje na rok 1414. Został on skierowany do wielkiego mistrza Zakonu Krzyżackiego w Prusach Michała Küchmeistera. Szymon prosił w nim o zwrot rzeczy, które zostały zrabowane poddanym arcybiskupa mieszkającym w kasztelanii nakielskiej. Dodajmy, iż tego haniebnego czynu dopuścić się mieli ludzie wielkiego mistrza $^{16}$. Wielce prawdopodobne jest to, że list ów stanowił ponowienie prośby wystosowanej przez arcybiskupa Mikołaja Trąbę do Henryka von Plauen, który zajmował urząd wielkomistrzowski bezpośrednio przed Michałem (Żnin, 11 listopada $1413 \mathrm{r}$. $)^{17}$. W formularzu listu wysłanego do Küchmeistera naszą uwagę zwraca szczególnie tytulatura użyta w stosunku do odbiorcy pisma (,,magnifice princeps et domine noster graciosissime"). Co istotne, w świetle najnowszych ustaleń historiografii tytulatura książęca była używana w stosunku do wielkich mistrzów dopiero po II pokoju toruńskim, a więc pół wieku później ${ }^{18}$. Nie mniej interesujący jest również podpis Szymona złożony pod tym listem, w którym występuje on jako „capellanus et orator” wielkiego mistrza, co raczej należy rozpatrywać w kategorii zwrotu kurtuazyjnego i nie powinno się go wiązać z pełnieniem jakiejś funkcji u boku adresata ${ }^{19}$. Na 27 lutego 1416 r. w Grucznie (,,datum in Gracz feria

${ }^{13}$ Lites ac res gestae inter Polonos Ordinemque Cruciferorum. Sprawy i spory pomiędzy Polakami a Zakonem Krzyżackim. Akta Postepowania przed wystannikiem papieskim Antonim Zeno z Mediolanu w latach 1422-1423, wyd. S. Jóźwiak, A. Szweda, S. Szybkowski, red. A. Szweda, Toruń 2015, s. 179 („Presentibus [...] Symone de Stawi altarista in Gneznensi ecclesia”).

${ }^{14}$ Gąsiorowski, Skierska, Szymon ze Stawu, s. 284.

${ }^{15}$ Znany jest jeszcze jeden list Szymona datowany w Kamieniu 24 marca 1430 r., który stanowił odpowiedź na pismo komtura człuchowskiego i dotyczył on sporu o jurysdykcję kościelną w pruskiej części oficjalatu kamieńskiego. Epistoła ta znana jest z niemieckojęzycznej kopii („,usschrifft”) przekazanej wielkiemu mistrzowi przez urzędnika krzyżackiego przy okazji złożonego zażalenia na oficjała kamieńskiego, który to miał wyrządzić wiele przemocy kapłanom uposażonym na posiadłościach Zakonu. Warto dodać, że w podpisie Maciejowic określił się kanonikiem kaliskim i oficjałem kamieńskim („Symon thumherre czu Kalis und officialis [sic!] czu Camen”). Niemniej ze względu na fakt, że mamy tu do czynienia odpisem listu nie uwzględniamy go w naszych rozważaniach. Za takim rozwiązaniem przemawiają brak adresatio, występowanie charakterystycznej dla niemieckojęzycznych pism salutacji (,unsern fruntlichen grus tzu vorn”), która nie stanowi raczej wiernego tłumaczenia listu łacińskiego, czy tytułowanie komtura jedynie jako „her Komptur”. Por. Geheimes Staatsarchiv Preusissches Kulturbesitz w Berlinie (dalej: GStAPK), XX Hauptabteilung (dalej: XX HA), Ordensbriefarchiv (dalej: OBA) nr 5319.

${ }^{16}$ Tamże, nr 2032.

${ }^{17}$ Tamże, nr 2009 („,datum in Zneno sabbato ipso die sancti Martini confessoris gloriosi etc.”).

${ }^{18}$ A. Szweda, „Princeps et consiliarus Regni Poloniae”. Król i wielki mistrz w latach 14661497, w: Od traktatu kaliskiego do pokoju oliwskiego. Polsko-krzyżacko-pruskie stosunki dyplomatyczne w latach 1343-1660, red. A. Bues i in., Warszawa 2014, s. 241-260.

${ }^{19}$ „Symon canonicus Lanciciensis et officialis Camenensis etc. vestre dominacionis capellanus et orator". Por. GStAPK, XX HA, OBA nr, nr 2009. 
quinta ante carnispirivium") datowany jest kolejny list Maciejowica, który i tym razem został wyekspediowany do Malborka. Wystawca pisma skarżył się wielkiemu mistrzowi na zrabowanie Gruczna przez Krzyżaków. Naszą uwagę po raz kolejny naszą uwagę zwraca adres epistoły, w którym zwierzchnik zakonu został nazwany wielmożnym i najjaśniejszym księciem (,,magnifico ac serenissimo principi et domino, domino Michaeli magistro generali ordinis beatae Marie Virginis in Prussia domino graciosissimo"). Niestety, z punktu widzenia naszych rozważań, w miejscu, w którym zapisana została tytulatura Maciejowica dokument jest uszkodzony i możemy odczytać jedynie fragment podpisu (, $\mathrm{Si}[\mathrm{mon}]$ canonicus Lanciciensis et $[\ldots]$ vestre $\left.\mathrm{s}[\ldots]^{\prime \prime}\right)^{20}$. $\mathrm{Z}$ kolei na 4 listopada $1425 \mathrm{r}$. datowany jest kolejny wytwór kancelarii znajdującej się pod zarządem Szymona. Także i ten list zaadresowany został do zwierzchnika Zakonu - tym razem Pawła von Rusdorf. Poza interesującą nas tematyką źródło to wyśmienicie pokazuje realia ówczesnej komunikacji. Z treści pisma dowiadujemy się, że w godzinach przedpołudniowych (,hora tertiarum”) przybyli do niego niewymienieni z imienia pisarz Rusdorfa oraz sędzia ziemi tucholskiej z pytaniem, czy arcybiskup Wojciech Jastrzębiec w dniu jutrzejszym (tzn. 5 listopada) przybędzie na uprzednio umówione spotkanie $\mathrm{z}$ wielkim mistrzem. Maciejowic stwierdził w responsie, że nie jest mu to wiadome i gdy tylko czegoś się dowie prześle wielkiemu mistrzowi stosowną wiadomość $^{21}$. Finalnie okazało się, że prymas nie przybędzie na spotkanie, ale w swoim imieniu przysłał trzech „większych” prałatów kapituły gnieźnieńskiej (,tres maiores dicte sue ecclesiae Gneznensis pralatos ad vestram magnificenciam suo nomine expedivi") ${ }^{22}$, którzy dotarli do Kamienia chwilę po zachodzie

${ }^{20}$ Tamże, nr 2310.

${ }^{21}$ Wedle itinerarium wielki mistrz 4 listopada 1425 r. przebywał w Tucholi. W związku z powyższym do ewentualnego spotkania większych prałatów z Rusdorfem doszło najprawdopodobniej w Tucholi. W grę wchodzić mogły również Chojnice oraz Człuchów, tym bardziej, że w Człuchowie jego pobyt potwierdzony jest w dniach 6-7 listopada. Por. C.A. Lückerath, Paul von Rusdorf. Hochmeister des Deutschen Ordens 1422-1441 (seria: Quellen und studien zur Geschichte des Deutschen Ordens, Bd. 15, hrsg. von Klemens Wieser), Bad Godesberg 1969, s. 213.

${ }^{22}$ Kolejność dostojeństw prałackich w kapitułach średniowiecznych była ściśle określona i tzw. maiores prelati to w przypadku archidiecezji gnieźnieńskiej: prepozyt, dziekan i archidiakon. W interesującym nas okresie beneficjum prepozyta dzierżone było przez Mirosława z Brudzewa, jednak przebywał on na stałe w Rzymie (M. Czyżak, Kapituła katedralna w Gnieźnie w świetle metryki z lat 1408-1448, Poznań 2003, s. 375-377). Zachowana baza źródłowa nie rozstrzyga jednoznacznie kto zajmował wówczas dziekanię gnieźnieńską. Wincenty z Marcinkowa pełnił tę godność w latach 1412-1425, jednak zmarł po 4 lipca 1425 r. (tamże, s. 400-401), zaś jego następca - Jan z Czechla objął dziekanię dopiero przed kwietniową kapitułą generalną w 1426 r. (tamże, s. 336-337). Tamtejszym archidiakonem był - bratanek biskupa poznańskiego Andrzeja Łaskarza i wikariusz generalny poznański - Mikołaj Kicki (tamże, s. 367-368). Z kolei kantoria znajdowała się w posiadaniu Jana z Brzostkowa (tamże, s. 334-335), zaś scholastykiem był Piotr z Wolbromia i Lwowa, który jednak w 1425 r. nie był obecny na żadnym posiedzeniu kapituły (tamże, s. 387-388). Prałatura kustosza była wówczas obsadzona przez syna wojewody mazowieckiego Andrzeja - Stanisława Ciołka, jednak i ten nie bywał na posiedzeniach kapituły gnieźnieńskiej (tamże, s. 393). Ostatnim zajmującym nas beneficjum była kancelaria, w której posiadanie wszedł Świetopełk z Zadusznik (tamże, s. 397). Uwzględniając jednak nieobecności prałatów (prepozyt, archidiakon - który przynajmniej hipo- 
słońca („qui hodie in Camen hora quasi completorii iam venerunt”), zaś sama epistoła była pisana przez Szymona w nocy (,,hora noctis") ${ }^{23}$. Na uwagę, podobnie jak we wcześniejszych listach, zasługuje zwrot grzecznościowy oraz podpis. $\mathrm{W}$ pierwszym $\mathrm{z}$ wymienionych elementów formularza wielki mistrz ponownie został nazwany wielmożnym księciem (,,magnifice princeps domine noster graciocisissime"), zaś podpis przynosi nam informacje o posiadanych przez Szymona beneficjach oraz zawiera element kurtuazyjny, w którym tytułuje się on kapelanem wielkiego mistrza („Simon canonicus Calisiensis et officialis Camenensis vestre magnificencie cappellanus"). Ostatnie zachowane po dziś dzień pismo Szymona, jako oficjała kamieńskiego, wysłane zostało do zwierzchnika zakonu 13 marca $1435 \mathrm{r}$. z Cerekwicy Wielkiej. W liście tym Szymon wstawiał się u adresata w sprawie krzywd wyrządzonych jednemu z chojnickich kapłanów. Maciejowic nie omieszkał jednocześnie poinformować wielkiego mistrza o tym, że arcybiskup gnieźnieński Wojciech Jastrzębiec przeniósł go na urząd wikariusza in spiritualibus et temporalibus i oficjała w Kamieniu (po relatywnie krótkiej nieobecności związanej ze sprawowaniem przez niego urzędu oficjała pomorskiego). Również i tym razem epistoła obfituje $\mathrm{w}$ wiele milych słów skierowanych w stosunku do odbiorcy pisma. I tym razem nazwany został on wielmożnym i znakomitym księciem („magnifico et illustri principi et domino, domino Paulo de Rusdorff”), zaś Szymon określa się m.in. mianem kapelana wielkiego mistrza („,per vestrum serenisissimum capellanum Simonem canonicum Calisiensem vicarium in spiritualibus et temporalibus ac officialem Camenensem") ${ }^{24}$.

Na rok 1434 datowane sią dwa listy wyekspediowane przez Szymona - już jako oficjała pomorskiego (gdańskiego) - do burmistrzów i rady miasta Gdańska. W pierwszym z nich (Komorsko, 28 VII 1434 r.) oficjał zwrócił się z prośbą, aby rajcy nie czuli się urażeni, gdy on wraz z Bernardem, biskupem tytularnym Callipolis (,episcopi Calypolensis”)" ${ }^{25}$, wystąpią przeciw Jakubowi Jordanowicowi, ich kapelanowi i familiaresowi (,dominum Jacobum Jordani vestrum cappellanum sive familiarem"), który w czasie swojego poselstwa w Polsce oskarżył ich o symonię ${ }^{26}$. W podpisie Maciejowic używa - poza tytulaturą kanonika kaliskiego, wikariusza in spiritualibus i oficjała pomorskiego - grzecznościowego tytułu kapelana gdańszczan (,per vestrum cappellanum Simonem canonicum Calisiensem nec non vicarium in spiritualibus officialem Pomeranie"). Kolejny z zajmujących nas listów został sprokurowany 24 listopada 1434 r. w Gdańsku i dotyczył kwestii prawnych. Mianowicie, Szymon protestował wobec burmistrza i rajców gdań-

tetycznie powinien rezydować w Poznaniu - scholastyk i kustosz) wypada nam stwierdzić, że na rozmowy z wielkim mistrzem najprawdopodobniej oddelegowani zostali dziekan, kantor i kanclerz. Por. Ł. Włodarski, Posłowie arcybiskupów gnieźnieńskich do Prus w XV w. Przyczynek do badań nad otoczeniem prymasów Polski w późnym średniowieczu (w druku).

${ }^{23}$ GStAPK, XX HA, OBA, nr 4505.

${ }^{24}$ Tamże, $\mathrm{nr} 6955$.

${ }^{25}$ Szerzej na temat Bernarda zob. K.R. Prokop, Biskupi pomocniczy $w$ diecezjach polskich w dobie przedtrydenckiej (2. pot. XIII - 1. pot. XVI w.), Kraków 2002, s. 196-197 (Bernard - dominikanin, sufragan wrocławski w latach 1413-1435; zmarły przed 22 kwietnia 1435 roku).

${ }^{26}$ Archiwum Państwowe w Gdańsku, 300D43, sygn. 26. 
skich z powodu ukarania przez nich lekarza Augustyna (,,magistrum Augustinum medicum") należącego do stanu duchownego i żądał wydania go przed sąd kościelny ${ }^{27}$. Także i tym razem Maciejowic podpisuje się (nie licząc posiadanych przez niego beneficjów) jako kapelan włodarzy Gdańska (,per vestrum cappellanum Simonem canonicum Calisiensem et oficialem Pomeranie").

Jako kanonik kaliski i oficjał pomorski oraz kapelan wielkiego mistrza (,,per vestrum serenitatem cappellanum Simonem canonicum Calisiensem necnon oficialem Pomeranie") Szymon oprotestował u Pawła Rusdorfa obłożenie daninami Komorska Wielkiego - wsi należącej do stołu biskupów włocławskich. Także i tu - co, jak wynika z powyższych listów było w zwyczaju Maciejowica - zwierzchnik zakonu nazwany został wielmożnym $i$ znakomitym księciem („,magnifico et illustri princeps, domino Paulo de Rusdorff magistro generali ordinis beate Mariae Virginis domus Theutonicorum suo domino gracioso"). Niestety, list ten posiada jedynie datę dzienną , ,ipso die Simonis et Jude Apostolorum beatorum”, tzn. 28 października. Wiadomo również, że został nadany w Sobkowach koło Tczewa ${ }^{28}$. Niemniej uwzględniając lata pontyfikatu biskupa włocławskiego Władysława Oporowskiego (1434-1449) oraz okres sprawowania urzędu wielkomistrzowskiego przez Rusdorfa (1422-1441) wypada nam stwierdzić, że musiał on być sprokurowany w latach 1434-1441, mając jednak na uwadze tytulaturę pomorską użytą w tym liście przez Szymona oraz fakt, że Maciejowic już w marcu 1435 r. potwierdzony jest w Kamieniu, jako tamtejszy wikariusz in spiritualibus et temporalibus i zarazem oficjał należy zawęzić ten okres do roku 1434. W piśmie tym musimy również zwrócić uwagę na tytulaturę użytą przez Maciejowica w stosunku do Władysława Oporowskiego (,,reverendus in Christo pater et dominus meus, dominus Wladislaus episcopus Wladislaviensi cappellanus serenitatis vestre”). Określenie ordynariusza włocławskiego „swoim ojcem i panem” (a także nazwanie się jego kapelanem, co tylko umacnia tezę o kurtuazyjności tego terminu w listach Szymona) oraz miejsce wystawienia pisma (Subkowy, czyli wieś należąca do stołu biskupów włocławskich) są mocnymi poszlakami wskazującymi na fakt, że to właśnie Oporowski powołał Szymona na oficjalat pomorski, co jest o tyle istotne, iż w literaturze przedmiotu nie zostało dotychczas jednoznacznie rozstrzygnięte kto był rzeczywistym mocodawcą Szymona na na tymże urzędzie ${ }^{29}$.

\section{${ }^{27}$ Tamże, sygn. 30.}

${ }^{28}$ GStAPK, XX HA, OBA, nr 7849.

${ }^{29}$ Oficjałowie gdańscy od końca XIV w. byli powoływani przez Zakon Krzyżacki z grona swoich poddanych. W przeważającej większości łączyli oni ten urząd z plebanią przy kościele pw. św. Katarzyny na Starym Mieście w Gdańsku, zaś pod ich jurysdykcję wchodziła ludność Gdańska oraz archidiakonatu pomorskiego. Było to związane z chęcią uniknięcia przez Krzyżaków pozywania swoich poddanych przed sąd biskupa włocławskiego, który znajdował się w granicach Korony (por. Marian Biskup, Kultura, w: Historia Gdańska, t. I, Do roku 1454, red. E. Cieślak, Gdańsk 1978, s. 460-461). Wiadomo również, że w 1436 r. Władysław Oporowski próbował obsadzić ten urząd przez archidiakona pomorskiego Marcina ze Stawu co jednak spotkało się z ostrą reakcją ze strony rajców gdańskich. Wysłali oni protest do obradującego wówczas Soboru Bazylejskiego, który w 1439 r. nakazał Oporowskiemu przestrzeganie dawnego zwyczaju, tzn. aby oficjałem 
Prawdopodobnie tego samego roku biskup włocławski Władysław Oporowski wraz ze swoją kapitułą wystawił (nieposiadającą żadnych elementów datacyjnych) kredytywę dla kanonika kaliskiego, wikariusza in spiritualibus et temporalibus i oficjała w Gdańsku Szymona ze Stawu (,venerabilis vir dominus Simon canonicus Calisiensis necnon vicarius in spiritualibus et temporalibus ac officialis Pomeranie in Daniczke exhibitor presencium") w celu okazania jej przed wielkim mistrzem Pawłem Rusdorfem i zreferowania spraw dotyczących dóbr kościoła włocławskiego położonych na Pomorzu. Godny uwagi jest tytuł adresata, który określony został jako „magnifice princeps et domine, domine graciosissimo”, zaś tytulatura wystawców zapisana została nietypowo, ze względu na pominięcie imienia i godności biskupa ograniczając się jedynie do użycia zaimka osobowego ja (,ego et venerabiles fratres mei domini capituli ecclesie Wladislaviensis vestre magnificencie capellani" $)^{30}$.

Możemy w końcu porównać niektóre elementy formularza pism Szymona z epistołami polskich starostów nadgranicznych z 1. połowy XV stulecia. Co do tytulatury adresata, $w$ ich korespondencji wielki mistrz początkowo nazywany był „panem”, a w okresie późniejszym również „przyjacielem”. Niemniej nigdy nie spotkamy określenia „książę”. Należy jednak pamiętać, że starostowie byli urzędnikami państwowymi, a interesujący nas okres charakteryzował się wieloma napięciami. Dodać również trzeba, że datacje listów wysyłanych przez nadgranicznych administratorów były typowe dla późnego średniowiecza i zapisane zostały za pomocą kalendarza świąt kościelnych ${ }^{31}$. Podobnie zresztą, jak w przypadku epistoł sprokurowanych przez Maciejowica.

Reasumując Szymon ze Stawu był zaufanym współpracownikiem trzech kolejnych arcybiskupów gnieźnieńskich: Mikołaja Trąby, Wojciecha Jastrzębca oraz Wincentego Kota. Za takim stwierdzeniem przemawia fakt, że za pontyfikatów każdego z nich pełnił wysokie godności kościelne nadane z ich woli. Ponadto będąc oficjałem pomorskim (gdańskim) był blisko związany z biskupem włocławskim Władysławem Oporowskim. Wypada nam stwierdzić, że tytułowanie się kapelanem, w naszym przypadku wielkich mistrzów, bądź burmistrzów i rajców gdańskich, w świetle interesującej nas korespondencji nie wiąże się w żaden sposób z pełnieniem u odbiorcy listu funkcji o tej nazwie. Stanowi ono raczej zwrot

gdańskim ponownie został proboszcz kościoła pw. św. Katarzyny w Gdańsku (por. Marian Biskup, Archidiakonat pomorski diecezji włoctawskiej, w: Historia Gdańska, s. 611). W tej materii nie ferują wyroków również A. Gąsiorowski i I. Skierska (Początki oficjalatu, s. 19, przyp. 83). Niemniej musimy podkreślić, że Szymon ze Stawu jako urzędnik arcybiskupów gnieźnieńskich oraz biskupa włocławskiego Władysława Oporowskiego (za czym przemawia chociażby fakt, że był okazicielem kredytywy wystawionej przez ordynariusza włocławskiego i jego kapitułę) bez wątpienia był poddanym stronny polskiej. Być może za akceptacją takiego stanu rzeczy przez Krzyżaków stoją dobre kontakty Maciejowica z wielkim mistrzem czego przejawem mogło być tytułowanie zwierzchników Zakonu książętami? Niemniej kwestia ta wymaga dalszych, szczegółowych badań.

${ }^{30}$ Tamże, $\mathrm{nr} 7856$.

${ }^{31}$ Szweda, Organizacja i technika dyplomacji , s. 146-149. 
kurtuazyjny określający osobę duchowną ${ }^{32}$, czego dobitnym przykładem jest użycie tego słowa przez Władysława Oporowskiego, a także kapitułę włocławską w kredytywie adresowanej do wielkiego mistrza. Podobnie rzecz się ma z terminem „orator”. Stownik taciny średniowiecznej w Polsce podaje kilka znaczeń tegoż rzeczownika, m.in. mówca, kaznodzieja, orędownik oraz w kontekście stosunków dyplomatycznych: poseł, wysłannik, a także rzecznik ${ }^{33}$. Niemniej uwzględniając sprawowane przez Szymona urzędy i funkcje (wikariusz in spiritualibus et temporalibus, oficjał kamieński, tenutariusz klucza kamieńskiego - czyli osoba reprezentująca arcybiskupa jako właściciela dóbr stołowych położonych w obrębie władztwa krzyżackiego), które zaliczały go formalnie w poczet otoczenia arcybiskupiego ${ }^{34}$, a także charakter prezentowanej sprawy (prośba o zwrócenie zrabowanych rzeczy) chyba najtrafniejszym ze znaczeń rzeczownika „orator” wydaje się być słowo rzecznik, ewentualnie mówca. Z kolei użycie sformułowań typu „magnificus princeps et domius" stanowiło prawdopodobnie próbę upodobania się, a poniekąd wywyższenia ponad miarę, wielkiego mistrza w celu osiągnięcia korzyści, jak np. zwrot rzeczy zagrabionych przez ludzi wielkiego mistrza. Warto jednak zaznaczyć, że tytułowanie zwierzchnika Zakonu Krzyżackiego księciem staje się praktyką dopiero po 1466, a więc po podpisaniu tzw. II pokoju toruńskiego ${ }^{35}$, co sprawia, że Szymon używał tejże tytulatury na około pół wieku przed zakorzenieniem się jej w formularzu dyplomatycznym strony polskiej.

\section{BIBLIOGRAFIA}

\section{Źródła}

Archiwum Państwowe w Gdańsku

300D43, sygn. 26, 30.

Geheimes Staatsarchiv Preusissches Kulturbesitz w Berlinie

XX Haupabteilung, Ordensbriefarchiv, nr 2009, 2032, 2310, 4505, 5319, 6955, 7849, 7856.

Lites ac res gestae inter Polonos Ordinemque Cruciferorum. Sprawy i spory pomiędzy Polakami a Zakonem Krzyżackim. Akta Postępowania przed wystannikiem papieskim

${ }^{32}$ Stownik łaciny średniowiecznej w Polsce (t. 2, z. 1 (9), red. M. Plezia, Wrocław-Kraków-Warszawa 1959, s. 127-129) podaje m.in. takie znaczenie, jak: ksiądz, kapłan (należący do kleru parafialnego), wikary.

${ }^{33}$ Stownik taciny średniowiecznej w Polsce, t. 6, z. 7 (51), red. K. Weyssenhoff-Brożkowa, Kraków 1992, s. 1091-1092.

${ }^{34}$ Por. przypis 10 .

${ }^{35} \mathrm{O}$ stosowaniu tytulatury książęcej, jednak w odmiennych realiach politycznych (zależność lenna wielkiego mistrza wobec króla Polski po 1466 roku), por. Szweda, „Princeps et consiliarus Regni Poloniae", s. 241-260. 
Antonim Zeno z Mediolanu w latach 1422-1423, wyd. Sławomir Jóźwiak, Adam Szweda, Sobiesław Szybkowski, red. Adam Szweda, Toruń 2015.

\section{Opracowania}

Czyżak Marta, Kapituła katedralna w Gnieźnie w świetle metryki z lat 1408-1448, Poznań 2003.

Gąsiorowski Antoni, Skierska Izabela, Poczatki oficjalatu kamieńskiego archidiecezji gnieźnieńskiej (wieki XIV-XV), „Kwartalnik Historyczny”, 103 (1996) nr 2, s. 3-21.

Gąsiorowski Antoni, Skierska Izabela, Szymon ze Stawu, w: Polski Słownik Biograficzny, 50/2, z. 205, Warszawa-Kraków 2015, s. 282-284.

Dyplomatyka staropolska, red. Tomasz Jurek, Warszawa 2015.

Dyplomatyka wieków średnich, oprac. Karol Maleczyński, Maria Bielińska, Antoni Gąsiorowski, Warszawa 1971.

Kętrzyński Stanisław, Zarys nauki o dokumencie polskim wieków średnich,t. 1, Warszawa 1934.

Koczerska Maria, Kancelaria i dokumentacja kościelna, w: Dyplomatyka staropolska, red. T. Jurek, Warszawa 2005, s. 359-367.

Koczerska Maria, Zbigniew Oleśnicki i Kościół krakowski w czasach jego pontyfikatu 1423-1455, Warszawa 2004.

Librowski Stanisław, Wizytacje diecezji włocławskiej, cz. I, Wizytacje diecezji kujawskiej i pomorskiej, t. I, opracowanie archiwalno - źródłoznawcze, „Archiwa, Biblioteki i Muzea Kościelne", 8 (1964), s. 5-186.

Lückerath Carl August, Paul von Rusdorf. Hochmeister des Deutschen Ordens 1422-1441 (seria: Quellen und studien zur Geschichte des Deutschen Ordens, Bd. 15, hrsg. von Klemens Wieser), Bad Godesberg 1969.

Maleczyński Karol, Zarys dyplomatyki polskiej wieków średnich, cz. 1, Wrocław 1951.

Prokop Krzysztof Rafał, Biskupi pomocniczy w diecezjach polskich $w$ dobie przedtrydenckiej (2. pot. XIII - 1. pot. XVI w.), Kraków 2002.

Regesta historico - diplomatica Ordinis S. Mariae Theutonicorum 1198-1525, pars I, vol. I, bearb. Erich Joachim, hrsg. von Walther Hubatsch, Göttingen 1948.

Skierska Izabela, Dwór i urząd biskupi w późnośredniowiecznej diecezji poznańskiej, „Roczniki Historyczne”, 60 (1994) s. 185-202.

Słownik łaciny średniowiecznej w Polsce, t. 2, z. 1 (9), red. Marian Plezia, Wrocław-Kraków-Warszawa 1959;

Słownik łaciny średniowiecznej w Polsce, t. 6, z. 7 (51), red. Krystyna Weyssenhoff-Brożkowa, Kraków 1992.

Suchodolska Ewa, Kancelarie na Mazowszu w latach 1248-1345. Ośrodki zarządzania i kultury, Warszawa 1977.

Sułkowska-Kurasiowa Irena, Dokumenty królewskie i ich funkcja w państwie polskim za Andegawenów i pierwszych Jagiellonów (1370-1444), Warszawa 1977.

Sułkowska-Kurasiowa Irena, Polska kancelaria królewska w latach 1447-1506, Wrocław 1967.

Szweda Adam, Listy króla Polski Kazimierza Jagiellończyka do wielkich mistrzów zakonu krzyżackiego z lat 1447-1454, w: Bitwa pod Chojnicami 18 IX 1454 r.w tradycji historycznej i lokalnej, red. J. Knopek, B. Kuffel, Chojnice 2004, s. 14-32.

Szweda Adam, Listy Władysława Jagietly do wielkich mistrzów krzyżackich $w$ latach 1386-1434, w: Tekst źródta - krytyka, interpretacja, red. B. Trelińska, Warszawa 2005, s. 253-272. 
Szweda Adam, Organizacja i technika dyplomacji polskiej w stosunkach z zakonem krzyżackim $w$ Prusach $w$ latach 1386-1454, Torun 2009.

Szweda Adam, „Princeps et consiliarus Regni Poloniae”. Król i wielki mistrz w latach 1466-1497, w: Od traktatu kaliskiego do pokoju oliwskiego. Polsko-krzyżacko-pruskie stosunki dyplomatyczne w latach 1343-1660, red. A. Bues i in., Warszawa 2014, s. 241-260.

Szybkowski Sobiesław, Korespondencja książą mazowieckich z Rada Miasta Gdańska w latach 1466-1526, w: Dziedzictwo ksiązat mazowieckich. Stan badań i postulaty badawcze, red. J. Grabowski, R. Mroczek, P. Mrozowski, Warszawa 2017, s. 283-304.

Szybkowski Sobiesław, Listy książą mazowieckich do gdańskiej rady miejskiej (do końca wojny trzynastoletniej), „Archeion”, 113 (2012) s. 217-248.

Wilk-Woś Zofia, Późnośredniowieczna kancelaria arcybiskupów gnieźnieńskich (14361493), Łódź 2013.

Włodarski Łukasz, Posłowie arcybiskupów gnieźnieńskich do Prus $w$ XVw. Przyczynek do badań nad otoczeniem prymasów Polski w późnym średniowieczu (w druku).

\title{
SEVERAL COMMENTS ON THE FORMAT OF THE LETTERS WRITTEN BY SZYMON OF STAW, THE KAMIEŃ \\ AND POMERANIA OFFICIAL, TO THE GRAND MASTERS OF THE TEUTONIC ORDER IN PRUSSIA AND GDAŃSK COUNCILLORS
}

\begin{abstract}
Summary
The aim of this article is to present the format of the letters written by the Kamień official and curate in spiritualibus et temporalibus (temporarily the Pomerania official as well), Szymon Maciejowic of Staw, to addressees in Prussia, namely the Grand Masters of the Teutonic Order and Gdańsk councillors. Unfortunately, only seven original letters from that church dignitary survive to this day. Analysis of these letters reveals that Szymon called himself a chaplain (cappellanus) when writing letters to the aforementioned addressees. This polite term was, in fact, a synonym for 'clergyman'. It is also worth emphasizing that Maciejowic, in order to please the recipients and win their favour, frequently addressed the Grand Masters as dukes in his letters. It should be added that addressing the head of the Teutonic Order as a duke became a fairly common diplomatic practice in Poland only after the signing of the so-called Second Treaty of Toruń in 1466.
\end{abstract}

Key words: Prussia; Szymon Maciejowic of Staw; the Kamien officiality; the Pomerania officiality; the fifteenth century; diplomacy 